Spring 4-10-2013

\title{
Query Theory - Knowing what we want by arguing with ourselves
}

Elke Weber

Columbia University

Follow this and additional works at: https://fordham.bepress.com/psych_colloquia

Part of the Psychiatry and Psychology Commons, and the Psychology Commons

\section{Recommended Citation}

Weber, Elke, "Query Theory - Knowing what we want by arguing with ourselves" (2013). Psychology Colloquia. 7.

https://fordham.bepress.com/psych_colloquia/7

This Conference Proceeding is brought to you for free and open access by the Psychology at DigitalResearch@Fordham. It has been accepted for inclusion in Psychology Colloquia by an authorized administrator of DigitalResearch@Fordham. For more information, please contact considine@fordham.edu. 


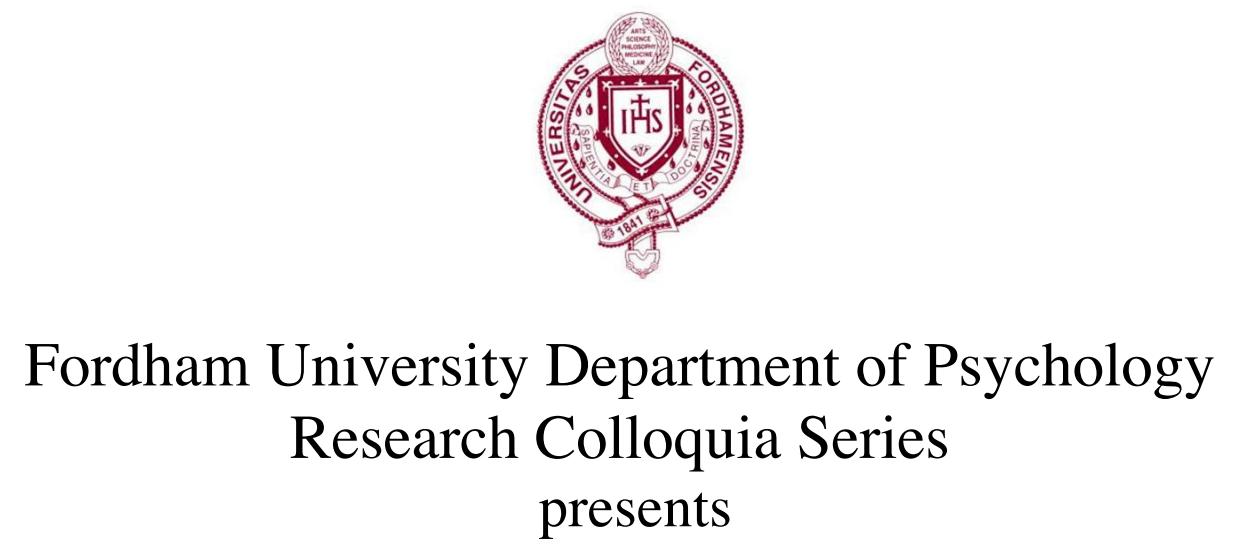

\section{Elke Weber, Ph.D.}

Jerome A Chazen Professor of International Business

Director, Center for Research on Environmental Decisions

Director, Center for the Decision Sciences

Columbia Business School

\section{Query Theory: Knowing What We Want by Arguing with Ourselves}

Psychologists and behavioral economists agree that many of our preferences are constructed, rather than innate or pre-computed and stored. Little research, however, has explored the implications that established facts about human attention and memory have when people marshal evidence for their decisions. This talk provides an introduction to Query Theory, a psychological process model of preference construction that explains a broad range of phenomena in individual choice with important personal and social consequences, including our reluctance to change and excessive impatience when asked to delay consumption.

\section{Wednesday, April 10, 2013 \\ 11:30 am \\ Freeman Hall, Room 103 \\ Fordham University at Rose Hill}

